\title{
KIRJALlisUUdEN KÄYTTÖ - OMAN KÄSITYSKYVYN TYÖSTÄMINEN
}

\author{
Risto Eräsaari: VTT, Viitasaari \\ risto.erasaari@helsinki.fi
}

Janus vol. 28 (4) 2020, 392-395

Kulttuurin ja ihmiskunnan odotushorisontin aavistelun ajatellaan ohjaavan kaunokirjallisuuden äärelle. Kaunokirjallisuuden käyttöä sosiaalityön opetuksessa käsitellyt artikkeli (Janus 2/2020) tuntui puhuvan kirjallisuuden puolelta saatavasta avusta tutkimukselle vaikeista asioista muodostuvan todellisuuspuheen ja kohteen luovan näkökulman avaamisessa. Kirjallisuus - esteettisen kokemuksen kannattelema tuntemiskyky - auttaa selkeyttämään ajatuksia ja rohkaisee kirjottamaan ennen kuin tietää, mitä aiheesta aikoo sanoa, mutta tunnetusti kirjallisuutta - edelleen on puhe kaunokirjallisuudesta - käytetään myös eettisessä kasvatuksessa ja se voi suuntautua nykyisyysinterventiota toteuttavana kulttuuritekniikkana ennemminkin terapiaan tai uskontoon vetoavaan itsesuojeluun kuin aikalaisuuden ymmärtämiseen. Esimerkiksi lähiluvun (close reading) ja radikaalipedagogiikan esteettisten kompetenssikeskusten vanavedessä vähät välitetään historiallisesta oppineisuudesta ja itseymmärryksen selkeyttämisestä eikä näin ollen ymmärretä kirjallisuuden käyttöä oman käsityskyvyn työstämisessä: siinä, miten asiat näkee ja mitä niiltä odottaa.

Ei ihme, vaikka artikkelin innoittajana olisi ollut monille aloille levittäytyvään maagiseen - yhtä hyvin voimaa ja siunausta kuin puutetta kirousta ymmärtävään - realismiin nojautuva (uuden) nykyisyyden haave sekä sen ajatusmaailmoihin kuuluva pinnistelevää "kimmoisuutta" ja teollista "sisällöntuotantoa" henkevämpi maailmankaikkeutta sopuisasti syleilevä suhtautuminen "epäuskottavuuteen" tai hakeutuminen laimennettuun "olemattomuuteen". Tuskan lieventämisessä ei ole mitään pahaa, mutta kriittisyyttä edellyttävässä tutkimuksen maailmassa tullaan välineellisen käytön mukana helposti jatkaneeksi tavallista frontaaliopetuksen maailmaa piittaamatta siltä puuttuvasta kyvystä tehdä ymmärrettäväksi salattuja mahteja tai pelastaa äärettömässä ehdottomuudessaan epäselvälle elämälle mieli. Aivan kuin kirjallisuudelta ei enää pyydettäisi muuta kuin tallennuksia ja dokumentaatioita.

"Kirjallisessa tietokirjallisuudessa" avainasemassa on tutkijalle suotu kirjallinen vapaus valita esitystapa ja tyyli (esimerkiksi) elämänkerta- ja tapaustutkimuksessa, ajattelun näkyviin jättävässä mutta myös tunteet näyttävän esseemuodon käytössä sekä muun muassa ensimmäisen persoonan ilmaukset sallivassa omakohtaisessa tieteen popularisoinnissa. Kirjallisuuden käyttö on silloin erilaisten vapauksien ottamista tutkimusmaailmassa. Oli kiinnostuksen kohteena kumpi tahansa, realismin taika tai kirjoittajan vapaus, oman itsen työstäminen on kaunokirjallisuuden 
käytössä niin ensisijaista, että totuudellekin voi olla edullista jäädä paljastumatta.

Mikä tahansa kirjallisuus ei kelpaa oppaaksi, kun halutaan astua niille alueille, joilla asioita ei voida osoittaa pakottavasti, joilla asiat ovat miltei aina mahdollisia muttei koskaan välttämättömiä, joilla selventävät kokemukset kohdataan usein sattumalta ja joilla aikakauden perustavia konstitutiivisia tapahtumia koetaan todellisuudessa harvoin. Minkälaisen maailman ymmärtämiseen haastava ja minkälaisen kirjoittamisen ja ajattelun merkitystä takaava tulkintastrategia sitten hakeutuu kaunokirjallisuuden käyttämiseen?

Maagisessa realismissa ei antauduta ääripäille, vaan tavoitellaan yhteensopimattomien asioiden mahduttamista (ilman lopullisen ajattelun himoa) yhteiseen kohtalonkysymyksiä käsittelevään todellisuuteen. Eksistentialistit olettavat kaikkialle kurkotellen ja usein oppimestarinsa ohittaen itsepintaisesti, että olemista on. Uskonnolliseen kokemukseen kuuluu luottamuksen kääntäminen salattua, suojavärin tai henkisen vakuutuksen olemattomuudelle antavaa Jumalaa kohtaan. Hirvittävää kokemusta tai järkyttävää kauneutta ei ilmaista järjellä eikä perustella vaan astutaan olettamuksia ja edellytyksiä aukaisevalle alueelle. Kyse on lähtökohdista, edellytyksistä, olettamuksista, perusteista, väitteistä jne., ja hyvä niin, datadeterminismi on haastettu.

Esikäsitteellisen ajattelun piirissä ajaudutaan usein jumaloimaan "ylintä" tai "alinta", yhtä aikaa sekä jumalallista (järjestystä) että aistillista (järjestyksen uhkaa), mutta harvoin työstetään sitä, mikä on niiden välillä. "Tulen" ja "veden" välillä ei voi olla mitään. Mieleen tulee eritoten realismin sosiaalinen kuri: romaanin rivien välissä puhuu piilevä kaikkitietävän mestarin tai kertojan ääni, joka toki voi olla lukijaa pohdintoihin patistavaa puhetta. Useimmiten lausunnot ovat yhdistäneet maailman yhden ainoan tulkinnallisen keskuksen tai aforistisen kielen ympärille eikä vangittujen henkilöhahmojen kuulu pelätä, ettei elämässä ole järkeviä sääntöjä eikä omaksua sivuttaista liukumista, kaarroksia tai etenemistä viistosti. Ne houkuttelevat lukemaan teoksia oikean henkilön elämäntarinoina ja pyydystävät arkipäivän mukaan diskurssiin.

Taide "tekee näkyväksi", sanoi Paul Klee, mutta miten se asiat näkee ja mitä niiltä edellyttää? En nyt puhu ilmaisun kielen ja kuvailun venyttämisestä rajamaille, lähelle "sanatonta", "puhdasta näkemistä", "läpikuultavuutta" tai "soinnukkuutta". Eihän kirjallisuus pääse puhtauteen eikä teksti koskaan täydellisyyteen. Puhun tyytymättömyydestä nykymaailmaan ja sen seurauksesta, siitä, ettei kohteesta voi antaa valoisaa kuvaa. On siedettävä rankkoja kokemuksia, uskallettava jättäytyä ratkaiseviin kokemuksiin, suostua epäuskottavalta tuntuvaan "olemattomuuden valoon". Jos poissaolevat ovat kuolleet ja läsnäolevat löyhkäävät, kirjallisuus ei toimi päämäärärationaalisena todellisuuden tietämisen laitteistona, joka asettaa representaatiot ja totuudenkaltaisuudet näkyville ja näytteille.

Lauseen virtuositeetin ja sanojen mahdin perusteisiin menemättä voi sanoa, että sanojen käytön vuoksi näkemys todellisuudesta on hämärä, sillä sanat tekevät automaattisesti kaiken havaitse- 
misen abstraktiksi. Kielen - jota kukaan ei omista - tehtävänä ei yksin ole kertoa, miten maailma on, vaan myös tehdä se hyvässä mielessä epäselvemmäksi, joten siihen kuuluu se, että pystyy olemaan epävarma, hapuileva ja epäilevä ärsyttävästi syitä ja tosiasioita havittelematta. Tätä (yhä vain) kutsutaan negatiiviseksi kyvyksi.

Radikaaliksi negativiteetiksi kutsuttu ominaispiirre ulottuu Rimbaudin hiljaisuudesta ja Musilin loppuun saattamatta jääneestä mestarinteoksesta John Cagen äänettömän musiikin ja Yves Kleinin tyhjien näyttelyjen kautta julkaisemattomiin ja kirjoittamattomiin kirjoihin, mutta se ei ole kirjallisuuden katoamista eikä kirjailijan kuolemaa, vaan maailman katoamista kirjailijalta. Aivan toista on kirjallisen kielen antirealistisuutta ja jokapäiväisistä kokemuksista erossa pysyttelemistä painottaneen, ainutlaatuisen kirjallisen kielen kehittäneen ja kirjallisuuden avaruuden avanneen Maurice Blanchot'n (2003) aavemainen ennustus, jonka mukaan kirjallisuus on matkalla kohti itseään. Se voitanee ymmärtää kirjallisuuden katoavuutta koskevaksi varuillaanolomuistutukseksi.

Kun realistien kokemukset tuntuvat vaientavan kirjallisuuden, tekevän sen kirjallisesti kykenemättömäksi, hävittävän siltä tilauksen ja tehtävän sekä usuttavan sen magian tielle, niin Blanchot'n vastaliikkeenä onkin "literature of the unword", uusi tapa kertoa ja samalla olla kertomatta, lainata huulet äänelle, joka ei kuulu sille, ja ymmärtää kieli sen tuonpuoleista ilmentäväksi prosessiksi, ei sanomattoman sanallistamiseksi. Se ei ole piittaamattomuutta tämän maailman asioista, vaan reikien puhkomista sanoihin, kunnes niiden takana oleva jokin tai ei mikään - alkaa tihkua esiin. Tässä valossa kirjallisuus on löytämistä, tutkimusta, joka toteutuu itsessään, mutta ei tieteen edellyttämän yksiselitteisyyden vaan poeettisen kielen suosiman moniselitteisuuden hengessä.

Se, miten asiat näkee ja mitä niiltä edellyttää, on ja vaatii oman käsityskyvyn jalostamista ja itseymmärryksen kehittämistä palvelevaa todellisuustarkkuutusta.

Kaunokirjallisella tyylillä tai äänensävyllä kirjoitettu sosiaalitieteellinen tutkimus voi osoittautua yhtä ongelmalliseksi kuin sosiaalitieteilijän pahamaineinen ainekirjoitus. Toisin kuin tutkijan, kirjailijan ei kuulu selittää tekstejään eikä kaunokirjallisessa tekstissä ole mitään sellaista, mitä kutsutaan "väärennykseksi", sillä kaunokirjallisuus on väärennöstä. Ainekirjoitustyyli puolestaan tyrmää omat valinnat ja vahvistaa ajattelun ja elämisen jatkamista siinä luulossa, että sanomisen ja ajattelun vapauksia voi ja pitää välttää.

Jorge Luis Borgesin tekstiä "Mies joka kirjoitti Quijoten" voidaan lukea monella tavalla, kirjallisuusteoreettisena pohdintana, esseenä fiktiivisistä kirjailijoista, novellina kirjoittamisesta ja lukemisesta. Sen yhtenä tarkoituksena on näyttää, että lukeminen ja tulkitseminen ovat sidoksissa kontekstiinsa ja riippuvat kirjoittajan nimestä: "Borges tuo esiin melko tyrmäävällä tavalla --ja kyseenalaistaa sen, mitä lukeminen ylipäänsä on tiedon hankkimisena", runoilija Peter Mickwitz (2002, 40, 41) huomauttaa, "tämä tarkoittaa, että lukiessaan teosta lukija toteuttaa omia intentioitaan, eikä itse teoksessa olevia 
intentioita", joten on kysyttävä "kuinka kirjoitamme teokset, joita luemme, kun luemme niitä oman aikamme ja persoonamme pohjalta”.

Oman itsen pitkälle viedystä työstämisestä ja fiktion merkityksestä käsitteellisenä abstraktiona ja kirjallisuutena - siis aivan muuna kuin jonain sepitettynä - kertoo Mickwitzin (2002, 42-23) huomautus, jonka mukaan kirjallisuustutkimuksen heikkojen kohtien löytämiseksi "on ehkä paljon tehokkaampi strategia tehdä siitä fiktiota kuin ryhtyä hedelmättömällä tavalla poleemiseksi”. Mickwitz kertoo nauttivansa hyvin kirjoitettujen ja omalle kirjoittamiselle olennaisten tekstien lukemisesta, mutta kertoo myös oppineensa "lukemaan tutkimuksia jossain määrin fiktiivisinä”.

Kaikilla on varmasti omakohtaisia kokemuksia siitä, kuinka teollisessa yhteiskunnassa ylösponnahtaneiden todellisuuksien näkökulmia punninnut, poliittisten positioiden ongelmia ratkonut ja pinnalliseen perspektivismiin miltei tukehtunut sosiaalitiede ei ole vain edustanut yhdessä journalismin kanssa kolmatta tietä vaan on ollut kirjallisen ja tieteellisen tradition hybridi
(Lepenies 1988). Mutta se onkin jo toinen juttu, jota ei kuitenkaan voi kuitata toteamalla, että miksi puhua kirjallisuuden käyttämisestä, kun on jo kirjallisuutta. Juuri nyt Düsseldorfin ammattikorkeakoulussa on "sosiaalityön ja yhteisömusiikin professuuri", Suomessa kirjoitetaan klassisesta musiikista "kuulokulmana" yhteiskunnallisiin asioihin ja toisen kuuntelun "myötävärähtelyn" tilaan (Torvinen ja Välimäki 2019) ja tietoviihde (infotainment) valtaa maailmalla alaa - hiljaista lukijalle osoitettua puhetta ei ole helppo erottaa puheesta, joka höynäyttää lukijan ymmärtämään keksityn oikeana.

\section{KirjallisuUs}

Blanchot, Maurice (2003) Kirjallinen avaruus. Helsinki: Ai-ai.

Lepenies, Wolf (1988) Between Literature and Science. The Rise of Sociology. Cambridge: Cambridge University Press.

Mickwitz, Peter (2002) Kirjailija kirjallisuuden tutkijana. Teoksessa Harri Veivo (toim.) Kirjallisuus on virhe. Helsinki: SKS, 31-43.

Torvinen, Juha \& Välimäki, Susanna (toim.) (2019) Musiikki ja luonto. Soiva kulttuuri ympäristökriisin aikakaudella. Turku: Otukirjat. 